\title{
Complex of measures to reduce noise on the environment and power plant personnel
}

\author{
Anastasia Evdokimova ${ }^{{ }^{*}}$ and Nina Rumyantseva ${ }^{1}$ \\ ${ }^{1}$ Peter the Great St.Petersburg Polytechnic University, 195251 St. Petersburg, Russia
}

\begin{abstract}
The article considers the sources of noise that have a negative effect on the electrician of the power plant, as well as on the environment. The analysis showed that noise is the main harmful production factor that adversely affects the working conditions of an electrician. In the course of the study, a set of measures to reduce the impact of industrial noise on the worker and the environment, including the installation of silencers, was proposed. The material used for the manufacture of the silencer, which can significantly reduce the level of industrial noise, was proposed. Recommendations for adjusting the work and rest regime were developed, and more effective personal protective equipment for an electrician was selected..
\end{abstract}

\section{Introduction}

The creation of safe and healthy working conditions at production site continues to remain a very pressing issue. The principle of labour protection consists in ensuring safe working conditions for a worker at production site, an enterprise through compliance with hygienic norms and rules, state standards, federal laws [1,2]. The life and health of the worker and, consequently, his ability to work depends on the level of safety at work. World statistics states that 3 million workers die every year from work-related injuries and occupational diseases [3]. The growth of injuries, the number of deaths, the increase in occupational diseases at work - all this provides the foundation for the development and improvement of measures aimed at minimizing the impact of harmful and hazardous factors on workers around the world. That is why this subject is topical.

\section{Methods and materials}

The purpose of this study is to develop measures to reduce the level of industrial noise at the workplace of an electrician. In order to accomplish this purpose, a number of tasks were completed:

1. Analysis of noise affecting the worker.

2. Detection and analysis of noise sources.

\footnotetext{
* Corresponding author: Nastasya.evdokimova.1999@mail.ru
} 
3. Development of a set of measures to reduce the impact of industrial noise on an electrician.

In order to solve these tasks, a number of scientific research methods were applied. At the initial stage, the problem was formulated. The next step was a survey of a specific workplace. In order to form a theoretical knowledge base in the area under study, a list of domestic and foreign literature, regulatory legal documents was studied. The final stages included: analysis of noise sources at the studied workplace, synthesis of the obtained data, specification of methods for dealing with noise.

\section{Results}

An electrician at the power plant performs maintenance work on the equipment of this enterprise. This position can be occupied by a person who has reached the age of 18 , who has professional training in this specialty, who has passed the exam for admission to work. The work of an electrician includes: maintenance of the equipment of the enterprise; ensuring the set mode for voltage, load, temperature; control of the substation operating mode; fixing the load on outgoing connections supplying consumers [4,5]. An electrician is responsible for the maintenance and trouble-free operation of electrical equipment every work shift. The work shift of the specific electrician is 12 hours.

At the studied workplace the noise class of working conditions was established at 3.1. (harmful working conditions) [6]. The worker is exposed to the negative effects of industrial noise. The sources of this noise are the equipment used in the workshops (turbine units, turbines, compressors, pipelines, valves). The data from the special assessment of working conditions states that the equivalent sound level in the work area of an electrician amounts to $87 \mathrm{~dB}$. This value exceeds the maximum permissible level for constant noise at workplaces of industrial premises by $7 \mathrm{~dB}$ [7]. Such exposure to noise can lead to negative consequences. These include occupational diseases, cardiovascular diseases, neuroses $[8,9]$. To eliminate or mitigate such impact, there is a need to develop new or improve old methods of noise control [10]. The most commonly used methods are noise control along the path of noise propagation or at the noise receiving end.

As a method of control at the noise receiving end, it is proposed to replace the earplugs that the electrician has with anti-noise headphones. They enable the worker to react to information received from the outside (alarm signal, information from colleagues). Depending on the make and model, the headphones can have a noise canceling effect of 37 $\mathrm{dB}$.

To reduce noise along the path of its propagation, it is proposed to install a silencer in the gas-air ducts. Based on the data of a special assessment of working conditions, a silencer of the kind was designed (fig. 1). 


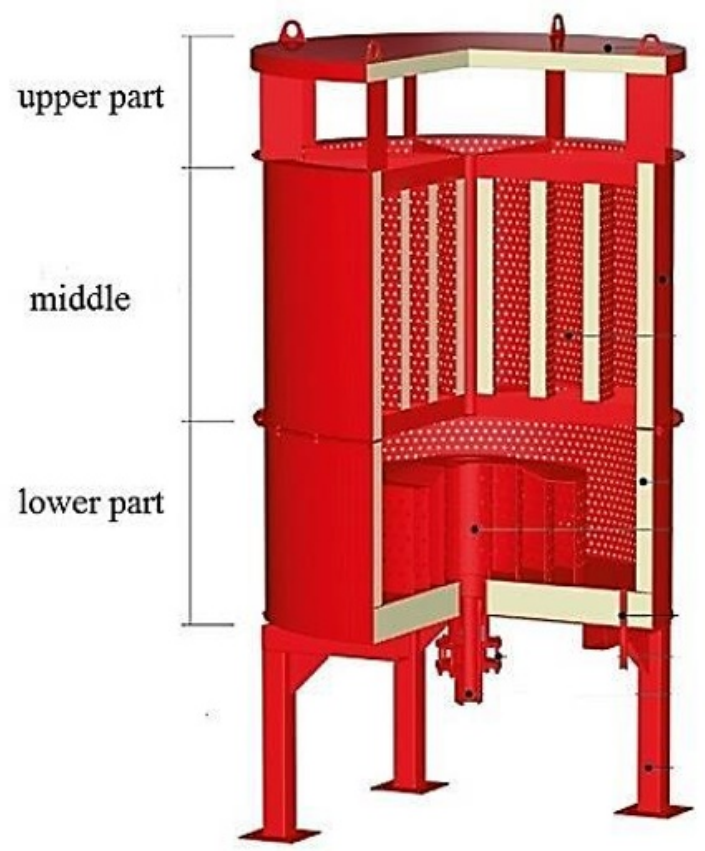

Fig. 1. Steam discharge silencer for sound level of 80-100 dB.

The top upper part is to prevent precipitation from the atmosphere from entering the silencer. The middle is a continuation of the body; sound-absorbing cassettes are installed inside, consisting of PTE basalt slabs, limited by glass fiber fabric and perforated stainless steel sheets. The soundproofing of the body is made in a similar way. The cassettes create a sound-absorbing volume in the form of annular channels along which the discharged medium moves. In order to use the silencer effectively, it is necessary to know the sound insulation index of the silencer $(\mathrm{dB})$. When using the silencer at low frequencies, the sound insulation index of the material used will be:

$\mathrm{R}_{\mathrm{k}}=\mathrm{L}-\mathrm{L}_{\mathrm{H}}-10 * \lg \alpha_{\mathrm{LIN}}+\Delta+5=87-80-10 * \lg 0,02+1+5=30 \mathrm{~dB}$,

where $\mathrm{L}$ is the sound pressure level of the noise source in the working area, $\mathrm{dB}$;

$\mathrm{LH}$ is the permissible sound pressure level, $\mathrm{dB}$;

$\alpha_{\text {LIN }}$ is the sound absorption coefficient of the inner lining of the silencer;

$\Delta$ is the adjustment, $\mathrm{dB}[11,12]$.

More detailed analysis can be performed after spectral analysis of the noise source. Using the data obtained, the occupational safety department at production site will be able to select noise silencers with the required parameters, which will effectively help to reduce the impact of noise on the worker. The lower part is a heat and sound insulated body. Steam is supplied by connecting the exhaust pipe to the silencer pipe. It is recommended to use basalt fiber as a manufacturing material [13]. The steam pressure in the pipe before the relief valve is 27 $\mathrm{MPa}$, the temperature is below $570{ }^{\circ} \mathrm{C}$.

Protection by time is an additional effective method of controlling noise in the tested workplace. Replacing a working day from 12 hours to 8 hours will lead to a decrease in the equivalent sound level from $87 \mathrm{~dB}$ to $83 \mathrm{~dB}$. 


\section{Discussion}

With the help of various methods of scientific research, certain data were obtained, on the basis of which measures to improve working conditions at the workplace of an electrician of an electric power plant were proposed, namely, to reduce the impact of industrial noise:

1. Replacement of the personal protective equipment in use with a more modern, effective one.

2. Introduction at production site of steam discharge silencers for a sound level of 80-100 $\mathrm{dB}$, providing a decrease in the level of industrial noise.

3. Application of protection by time.

The developed measures can be useful at their introduction at a given enterprise.

\section{Conclusion}

The application of a set of measures, including the installation of steam discharge silencers in the gas-air ducts for a sound level of 80-100 dB, the correct and individual selection of personal protective equipment and a reduction in the working day to 8 hours is a reasonable solution. Replacing a working day from 12 to 8 hours will reduce the equivalent sound level from $87 \mathrm{~dB}$ to $83 \mathrm{~dB}$. The synergism of the use of therapeutic and prophylactic, engineering, technical, organizational and other methods will lead to better results [14,15]. The state of working conditions at the workplace is the main indicator of the efficiency of labour protection at any enterprise [16].

\section{References}

1. K. Wong, A. H. S. Chan, Emerging issues in occupational safety and health, International Journal of Environmental Research and Public Health, 15(12) (2018).

2. F. Nari, Y. K. Kim, S. H. Kang, E. Park, S. Jang, Association between occupational noise and vibration exposure and insomnia among workers in korea, Life, 10(4) (2020)

3. J. Ladou, L. London, A.Watterson, Occupational health: A world of false promises, Environmental Health: A Global Access Science Source, 17(1) (2018).

4. TI R M-068-2002 Tipovaya instrukcziya po okhrane truda dlya e lektromon-tera po obsluzhivaniyu podstanczij, [E`lektronny’j resurs], URL:

http://docs.cntd.ru/document/1200031542 (data obrashheniya: 20.10.2020).

5. E.A. Logacheva, V.G. Zhdanov, Razrabotka innovaczionnoj programmy $N P O$ «E 'lektromonter po remontu i obsluzhivaniyu e lektrooborudovaniya v sel 'skokhozyajstvennom proizvodstve»,Vestnik APK Stavropol`ya, Stavropol`: Stavro-pol`skij gosudarstvenny`j agrarny j universitet, s. 9-12 (2013)

6. Federal 'ny`j zakon "O speczial ’noj oczenke uslovij truda" ot 28.12.2013 N 426-FZ (poslednyaya redakcziya), [E`lektronny’j resurs], URL:

http://www.consultant.ru/document/cons_doc_LAW_156555/(data obrashheniya: 20.10.2020)

7. SanPiN 2.2.4.3359-16 Sanitarno-e pidemiologicheskie trebovaniya k fi-zicheskim faktoram na rabochikh mestakh, [E`lektronny`j resurs], URL: http://docs.cntd.ru/document/420362948 (data obrashheniya: 20.10.2020).

8. V.V. Stolyarov, Analiz negativnogo vozdejstviya faktorov shuma i vibra-czii, Arkhitekturno-stroitel `ny`j i dorozhno-transportny`j kompleksy`: pro-blemy`, perspektivy`, novaczii, Omsk: Sibirskij gosudarstvenny`j avtomobil`-no-dorozhny`j universitet (SibADI), s. 1018-1021 (2016) 
9. E. I. Denisov, Noise at a workplace: Permissible noise levels, risk assessment and hearing loss prediction, Health Risk Analysis, (3), 13-23 (2018)

10. K.E Pushin, I.L. Bukharina, T.T. Kaverzneva, S.A. Gagarin Shum, Opredelenie. Metody 'rascheta. Izmereniya: uchebno-metodicheskoe posobie, Izhevsk: Izdatel'-skij czentr «Udmurtskij universitet», 260 s (2018)

11. E.A. Stepanova, S.A. Gordeeva, Issledovanie proizvodstvennogo shuma, [E`lektronny $\mathrm{j}$ resurs], URL: http://bek.sibadi.org/fulltext/ED1810.pdf (data ob-rashheniya: 20.10.2020)

12. GOST 31326-2006 (ISO 15667:2000) Shum. Rukovodstvo po snizheniyu shuma kozhukhami i kabinami (s Popravkoj), [E`lektronny`j resurs], URL: http://docs.cntd.ru/document/1200047928 (data obrashheniya: 20.10.2020).

13. S.A. Pilipenko, T.T. Kaverzneva, Raschet e `ffektivnosti ispol 'zovaniya zvukopogloshhayushhikh materialov $v$ czekhe sborki mashinostroitel nogo predpriyatiya, Nedelya nauki SPbPU: materialy` nauchnogo foruma s mezhdunarodny`m uchastiem. Institut voenno-tekhnicheskogo obrazovaniya i bezopasnosti, SPb.: Izd-vo Politekhn. un-ta, 298 s (s 137-139). (2015)

14. E. V. Klimova, A. Y. Semeykin, E. A. Nosatova, Improvement of processes of professional risk assessment and management in occupational health and safety system, Paper presented at the IOP Conference Series: Materials Science and Engineering, 451(1) (2018)

15. R. Miranti, J. Li, Working hours mismatch, job strain and mental health among mature age workers in Australia, Journal of the Economics of Ageing, 15 (2020)

16. A.Yu. Svetlakova, T.T. Kaverzneva, Razrabotka universal nogo algo-ritma vy bora instrumentov oczenki sostoyaniya uslovij truda, XXI vek: itogi proshlogo i problemy' nastoyashhego plyus, Penza.: Penzenskij gosudarstvenny`j tekhnologicheskij universitet, s 150-153 (2019) 